\title{
Oxytocinase in Plasma and Placenta in Normal and Prolonged Labour
}

\author{
V. S. MATHUR,*† M.D. ; J. M. WALKER,* D.M., B.SC.
}

Brit. med.F., 1968, 3, 96-97

\begin{abstract}
Cummary : In prolonged labour (dystocia) the level of activity of the enzyme oxytocinase is increased in the plasma and decreased in the placenta ; the ratio of its activity in the placenta to that in plasma is less than half that found in normal labour. A possible explanation is that oxytocinase is derived mainly from the placenta and that during prolonged labour the enzyme escapes into the maternal blood stream.
\end{abstract}

\section{Introduction}

An enzyme, or enzymes, capable of inactivating oxytocin (oxytocinase) is present in the plasma and placenta of women during pregnancy. Increased oxytocinase activity in the plasma has been reported in prolonged labour (Babuna and Yenen, 1966), after infusions of oxytocin (Fylling, 1964 ; Riad, 1966), in delayed labour (Lambrinopoulos, 1964), and in multiple pregnancies (Melander, 1965). However, simultaneous estimations of activity in both plasma and placenta have not been recorded, either in normal or abnormal conditions.

We have compared the plasma and placental oxytocinase activities of 10 women in normal labour with those of nine women who had prolonged labour ; eight of the latter suffered from uterine inertia, and the remaining one had a transverse presentation. In the abnormal cases dilatation of the cervix was complete and there was no cephalopelvic disproportion. However, because of impaired uterine contraction progress of the second stage was so slow that in the opinion of the obstetrician in charge there would be danger to the mother and foetus if remedial measures were not carried out. These included infusion of oxytocin, application of forceps, and caesarean section.

\section{Methods and Materials}

Plasma.-About $5 \mathrm{ml}$. of blood was withdrawn from the cubital vein into a tube containing heparin and centrifuged. To $0.5 \mathrm{ml}$. of plasma was added $4.25 \mathrm{ml}$. of $0.066 \mathrm{M}$ phosphate

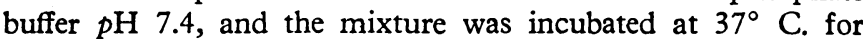
three minutes. Then $0.25 \mathrm{ml}$. of oxytocin (Syntocinon, $10 \mathrm{u} . / \mathrm{ml}$.) was added. After incubation for one minute a sample of $1 \mathrm{ml}$. was withdrawn, added to about $10 \mathrm{ml}$. of $0.25 \%$ acetic acid, and boiled to stop the reaction. This sample acted as a control. Another $1-\mathrm{ml}$. sample was withdrawn after 10 minutes. The volumes were made up to $25 \mathrm{ml}$. with distilled water, and the solutions were stored at $4^{\circ} \mathrm{C}$. until they were assayed.

Placenta.-The placenta was collected in ice immediately after delivery. After the membrane and clots had been removed under running tap-water 10 to 15 pieces were cut from different cotyledons and washed again in tap-water. From each piece a small portion of about $0.3 \mathrm{~g}$. was cut, dried on filter paper, and weighed. These portions were then homogenized in about twice their volume of ice-cold $0.9 \% \mathrm{NaCl}$ solution, and the homogenate was centrifuged at 2,000 r.p.m. for 30 minutes. One millilitre of supernatant represented about $0.5 \mathrm{~g}$. of tissue.

\section{- Department of Pharmacology, University of Oxford.}

t Commonwealth Scholar from India.
One millilitre of supernatant was added to $3.75 \mathrm{ml}$. of buffer and incubated; after three minutes $0.25 \mathrm{ml}$. of oxytocin solution was added. Samples were withdrawn as described for plasma.

Estimation of Activity.-The oxytocin content was estimated by a four-point assay on the superfused rat uterus (Gaddum, 1953), the solution described by Munsick (1960) being used. Protein determinations were done by Folin's method, as described by Lowry et al. (1951). The rate of inactivation of oxytocin $\left(\mathrm{K}^{\prime}\right)$ was calculated from the formula $K^{\prime}={ }^{2.3} \log$ $\frac{a}{a-x}$, where $a$ is the activity of the control sample taken at 1 minute, $a-x$ is the activity remaining at time $t$, and $t$ is the time in minutes. Rydén (1966) has shown that at a concentration of $0.2-3 \mathrm{u} . / \mathrm{ml}$. the inactivation behaves as a first-order reaction.

The results are shown in the Table. The differences in mean rates of inactivation between normal and prolonged labour are significant for both placenta $(P<0.02)$ and plasma $(P<0.01)$. The difference between the mean ratios is highly significant $(\mathbf{P} \ll 0.01)$.

Rates of Inactivation of Oxytocin per mg. of Protein. Protein Content of Plasma was taken as $66 \mathrm{mg} . / \mathrm{ml}$.

\begin{tabular}{|c|c|c|c|c|c|c|}
\hline & & & & $\begin{array}{c}\mathrm{K}^{\prime} \text { Placenta } \\
\times 10^{3}\end{array}$ & $\begin{array}{c}\mathrm{K}^{\prime} \underset{\times 10^{3}}{\text { Plasma }} \\
\end{array}$ & $\frac{\mathrm{K}^{\prime} \text { Placenta }}{\mathrm{K}^{\prime} \text { Plasma }}$ \\
\hline $\begin{array}{l}\text { Norma } \\
1 \\
2 \\
3 \\
4 \\
5 \\
6 \\
7 \\
8 \\
9 \\
10 \\
\end{array}$ & $\begin{array}{l}\text { labo } \\
\because \\
\because \\
\cdots \\
\because \\
\cdots \\
\cdots \\
\cdots \\
\cdots\end{array}$ & $\begin{array}{l}\ldots \\
\therefore \\
\because \\
\therefore \\
\therefore \\
\therefore \\
\therefore \\
\therefore\end{array}$ & $\begin{array}{l}. \\
\because \\
\because \\
\because \\
\because \\
\because \\
.\end{array}$ & $\begin{array}{l}9 \cdot 4 \\
4 \cdot 1 \\
5 \cdot 3 \\
6 \cdot 0 \\
5 \cdot 4 \\
3 \cdot 2 \\
5 \cdot 1 \\
5.9 \\
8.9 \\
6 \cdot 8\end{array}$ & $\begin{array}{l}1.0 \\
0.3 \\
0.8 \\
0.6 \\
0.7 \\
0.7 \\
0.8 \\
0.9 \\
1.0 \\
1.0\end{array}$ & $\begin{array}{r}9.4 \\
13.7 \\
6.6 \\
10.0 \\
7.7 \\
4.6 \\
6.3 \\
6.5 \\
8.9 \\
6.8\end{array}$ \\
\hline $\begin{array}{l}\text { Mean } \\
\text { S.E. }\end{array}$ & $\ddot{x}$ & $\ddot{x}$ & $\because$. & $\begin{array}{l}6.0 \\
0.61 \\
\end{array}$ & $\begin{array}{l}0.8 \\
0.09\end{array}$ & $\begin{array}{l}8 \cdot 0 \\
0.84 \\
\end{array}$ \\
\hline \multicolumn{4}{|c|}{ 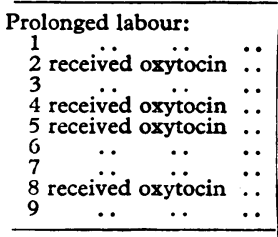 } & $\begin{array}{l}4 \cdot 5 \\
2 \cdot 4 \\
5 \cdot 9 \\
3 \cdot 7 \\
2 \cdot 4 \\
4 \cdot 2 \\
5 \cdot 7 \\
4 \cdot 2 \\
3.5\end{array}$ & $\begin{array}{l}1 \cdot 6 \\
1.0 \\
1.9 \\
1.2 \\
0.8 \\
1.5 \\
1 \cdot 1 \\
1.4 \\
1 \cdot 2\end{array}$ & $\begin{array}{l}2 \cdot 8 \\
2 \cdot 4 \\
3 \cdot 1 \\
3 \cdot 1 \\
3 \cdot 0 \\
2 \cdot 8 \\
5 \cdot 2 \\
3 \cdot 0 \\
2.9 \\
\end{array}$ \\
\hline $\begin{array}{l}\text { Mean } \\
\text { S.E. }\end{array}$ & $\because$ & $\because$ & $\because$. & $\begin{array}{l}4 \cdot 0 \\
0 \cdot 37\end{array}$ & $\begin{array}{l}1 \cdot 3 \\
0 \cdot 11\end{array}$ & $\begin{array}{l}3 \cdot 1 \\
0.26\end{array}$ \\
\hline
\end{tabular}

\section{Discussion}

These results show that in pregnancies where the labour is prolonged there is an increased oxytocinase activity in the plasma, confirming the findings of Babuna and Yenen (1966). The results also show that there is decreased activity in the placenta. The ratio of activities placenta: plasma is very much decreased in prolonged labour.

Eleven of the 12 patients investigated by Babuna and Yenen (1966) received infusions of oxytocin, and, since this is known to cause increased plasma oxytocinase (Fylling, 1964 ; Riad, 1966), their results may have been due to treatment with oxytocin rather than to prolonged labour itself. In our series 
four of the nine abnormal patients received oxytocin. The figures in the Table do not suggest any difference between those who were treated with oxytocin and those who were not.

Our results are compatible with the belief (Rydén, 1966; Page et al., 1961) that the plasma oxytocinase is mainly derived from the placenta. Schmorl (1893), and more recently Hamilton and Boyd (1966), have described in the human the separation of portions of syncytial trophoblast ("sprouts") and their entry into the maternal blood stream. If, as seems possible, this process of discharge of syncytial sprouts is increased when labour is prolonged, and if, as has been suggested (Ross, 1961), the syncytial trophoblast is the origin of placental oxytocinase, then prolonged labour would be likely to increase the activity of the plasma at the expense of the placenta. We are doing further experiments to test this hypothesis.

We are grateful to Mr. Arthur Williams for supplying us with material from patients under his care in the Nuffield Department of Obstetrics and Gynaecology, Oxford, and for helpful information about deportation of trophoblast.

\section{REFERENCES}

Babuna, C., and Yenen, E. (1966). Amer. 7. Obstet. Gynec., 94, 868.

Fylling, P. (1964). Acta obstet. gynec. scand., 43, 103.

Gaddum, J. H. (1953). Brit. F. Pharmacol., 8, 321.

Hamilton, W. J., and Boyd, J. D. (1966). Brit. med. 7., 1, 1501.

Lambrinopoulos, T. C. (1964). Obstet. and Gynec., 23, 780.

Lowry, O. H., Rosebrough, N. J., Farr, A. L., and Randall, R. J. (1951). 7. biol. CChem., 193, 265.

Melander, S. E. J. (1965). Acta endocr. (Kbh.), 48, Suppl. No. 96, p. 1. Munsick, R. A. (1960). Endocrinology, 66, 451.

Page, E. W., Titus, M. A., Mohun, G., and Glendening, M. B. (1961). Amer. Ұ. Obstet. Gynec., 82, 1090.

Riad, A. M. (1966). F. Obstet. Gynaec. Brit. Cwlth, 73, 977.

Ross, R. A. (1961). Amer. 7. Obstet. Gynec., 82, 1094.

Rydén, G. (1966). Acta obstet. gynec. scand., 45, Suppl. No. 3.

Schmorl, G. (1893). Pathologische-anatomische Untersuchungen über Puerperal-Eklampsie. Leipzig.

\title{
Cardiac Manifestations During a Coxsackie B5 Epidemic
}

\author{
M. HELIN,* M.D.; J. SAVOLA,* M.D. ; KAISA LAPINLEIMU, $\dagger$ M.D.
}

\begin{abstract}
Cummary : During a widespread Coxsackie B5 $S$ epidemic which occurred in Finland in the autumn of 196518 patients with acute myopericarditis were admitted to Kuopio Central Hospital (530 beds, representing a hospital district with 270,000 inhabitants) within a period of three months.
\end{abstract}

The mean age of these patients was 28 years. Twelve were males and six were females.

In 12 cases Coxsackie B5 virus and in one case Coxsackie $A 9$ virus were isolated from the faeces. A significant increase in neutralizing antibodies or high antibody titres ( $\geqslant 1: 128$ ) were noted in 16 cases against Coxsackie B5 and in one case against Coxsackie A9. In two cases the cause of the myopericarditis remained obscure.

All the patients had fever. Six showed all classical criteria of pericarditis : chest pain, pericardial rub, E.C.G. changes, and radiologically observable enlargement of the heart. As regards the various criteria, E.C.G. changes were found in all cases. Signs of cardiac tamponade were observed in one patient. Five, in addition, showed aseptic meningitis.

All the patients recovered. Twelve were re-examined at an average of seven months after discharge from hospital. All were symptom-free except one, who still showed E.C.G. changes.

\section{Introduction}

Interest in infections caused by Coxsackie B viruses has increased since improved techniques have made it possible to identify the causative factors in viral diseases. The most typical clinical conditions caused by them are pleurodynia, myalgia, aseptic meningitis, and pericarditis.

As long ago as the beginning of the last century certain cases of febrile disease resembling pleurodynia were reported in which pericarditis and exanthema were also observed (Jarcho, 1963). When pleurodynia, or Bornholm disease, reached epidemic proportions in Scandinavia in the 1930s, pericarditis was

* Central Hospital, Kuopio, Finland.

†Virological Laboratory, State Serum Institute, Helsinki. frequently an associated feature (Bing, 1933). In the 1950s, after Coxsackie B viruses had been discovered to be the cause of Bornholm disease, an obvious correlation was detected between these viruses and infectious heart diseases. The first observations were made on newborn infants with acute myocarditis in 1952 (Javett et al., 1956), and on adults with socalled acute benign pericarditis in 1957 (Fletcher and Brennan, 1957; Weinstein, 1957). Subsequently, numerous cases of pericarditis or myocarditis caused by Coxsackie viruses have been described (Smith, 1966).

The present paper is a report on 18 patients with carditis who, during a Coxsackie B5 epidemic occurring in Finland in 1965 , were all treated in the same hospital within a period of three months.

\section{Material}

Clinical Data.-In the latter half of 1965 a widespread epidemic due to Coxsackie B5 occurred in Finland. During this time a large number of patients with pleurodynia and/or meningoencephalitis were investigated at the outpatient department of the Kuopio Central Hospital (530 beds). The hospital district comprises 270,000 inhabitants in $16,700 \mathrm{sq}$. km. Only the most severely ill of these patients were admitted to hospital: aseptic meningitis 20 cases, carditis 18 , pleurodynia 10 , encephalitis 6 . The 18 patients (12 males, 6 females) with carditis (Table I) were mostly young adults-mean age 28 years. The mean interval between the onset of signs and symptoms and admission to hospital was 10 days. The preadmission diagnosis included pericarditis in six cases, cardiac infarction in one, acute appendicitis in one, pleurisy in one, congenital heart disease in two, endocarditis in two, acute infection in one, meningitis in one, and pleurodynia in three cases. Precordial pain, aggravated by movement and respiration, had been present in 12 cases. Two patients had experienced dyspnoea, and one had observed oedema before admission to hospital.

Virological Methods.-Virus isolations were performed in tissue cultures of primary human amnion cells, U-cells (a continuous amnion line), and monkey kidney cells. Typing was also made in tissue cultures, the neutralization test 